\title{
2021 Handbook of Florida Water Regulation: Protection and Management of Endangered Species ${ }^{1}$
}

\author{
Michael T. Olexa, Tatiana Borisova, and Jana Caracciolo²
}

\section{Preface}

This handbook is designed to provide an accurate, current, and authoritative summary of the principal federal and state (Florida) laws that directly or indirectly relate to agriculture. This handbook provides a basic overview of the many rights and responsibilities that farmers and farmland owners have under both federal and state laws as well as the appropriate contact information to obtain more detailed information. However, the reader should be aware that because the laws, administrative rulings, and court decisions on which this handbook is based are subject to constant revision, portions of this publication could become outdated at any time. Several details of cited laws are also left out due to space limitations. This handbook is provided as an educational text for those interested in water use and water resource issues in Florida.

This handbook is distributed with the understanding that the authors are not engaged in rendering legal or other professional advice, and the information contained herein should not be regarded as a substitute for professional advice. This handbook is not all inclusive in providing information to achieve compliance with the federal and state laws and regulations governing water protection. For these reasons, the use of these materials by any person constitutes an agreement to hold harmless the authors, the UF/IFAS Center for Agricultural and Natural Resource Law, and UF/IFAS Extension for any liability claims, damages, or expenses that may be incurred by any person as a result of reference to or reliance on the information contained in this handbook. Note: UF/IFAS is the acronym for University of Florida, Institute of Food and Agricultural Sciences.

\section{Endangered Species Overview}

Several laws have been enacted to protect endangered species in the United States. The Endangered Species Act (ESA) was passed by federal legislation in 1974 to protect species of fish, wildlife, and plants that are threatened with extinction as well as the ecosystems critical to the survival of those species. In many cases, these ecosystems are wetlands, so endangered species protection often includes water protection. The National Environmental Policy Act (NEPA) was passed to address adverse environmental impacts of laws. The Administrative Procedure Act requires public notice of proposed rules impacting the environment.

\section{What does ESA prohibit?}

The Endangered Species Act (ESA) prohibits anyone from taking any endangered species. "Taking” under the ESA basically means killing, trapping, harassing, hunting, collecting, or harming the species in any way.

The definition of taking has been extended by the federal courts to include the destruction of areas designated as

1. This document is FE592, one of a series of the Food and Resource Economics Department, UF/IFAS Extension. Original publication date October 1998. Revised June 2017 and April 2021. Visit the EDIS website at https://edis.ifas.ufl.edu for the currently supported version of this publication.

2. Michael T. Olexa, professor, Food and Resource Economics Department, and director, UF/IFAS Center for Agricultural and Natural Resource Law; Tatiana Borisova, associate professor, Food and Resource Economics Department; and Jana Caracciolo, student, Levin College of Law; UF/IFAS Extension, Gainesville, FL 32611.

The Institute of Food and Agricultural Sciences (IFAS) is an Equal Opportunity Institution authorized to provide research, educational information and other services

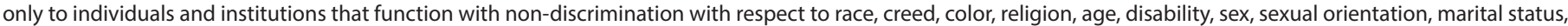

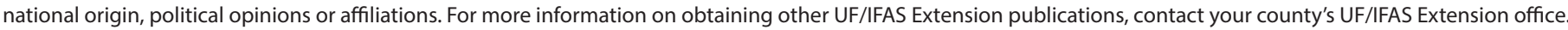
U.S. Department of Agriculture, UF/IFAS Extension Service, University of Florida, IFAS, Florida A \& M University Cooperative Extension Program, and Boards of County Commissioners Cooperating. Nick T. Place, dean for UF/IFAS Extension. 
"critical habitats" where the destruction or adverse modification might be reasonably expected to result in a reduction in the number or distribution of an endangered species, especially if it hinders the endangered species' ability to feed, shelter, and/or reproduce. Any adverse modification or destruction of critical habitat is restricted under ESA.

Nonpoint source pollution of such a habitat—and most agricultural operations (with the exception of concentrated animal feeding operations) are classified as nonpoint sources - that leads to the destruction or adverse modification of the habitat and results in a reduction in the number or distribution of an endangered species could be considered by the courts as a taking of endangered species. The owner of that nonpoint source may then be liable for a violation of the ESA and face the penalties under the ESA.

\section{Who enforces ESA?}

The US Fish and Wildlife Service (FWS) and the Fisheries Services of the US National Oceanic and the Atmospheric Administration (NOAA Fisheries) are the lead federal agencies in charge of implementing the ESA. However, the United States Department of Agriculture (USDA) is responsible for enforcing regulations specific to the import and export of plants listed under ESA as well as listed in the Convention on International Trade in Endangered Species and Wild Fauna and Flora (CITES).

ESA also directs FWS and NOAA Fisheries to cooperate to the maximum extent practicable with states in carrying out ESA rules. State agencies are therefore involved in activities such as pre-listing species conservation, listing species, habitat conservation planning, and more. As do all federal agencies, state and local agencies must also consult with FWS and NOAA Fisheries if a state or local action is likely to adversely affect listed species or a designated critical habitat.

\section{What are the penalties under ESA?}

Civil penalties may be enforced by any of the federal agencies in amounts of up to $\$ 25,000$ per violation (for knowing violators and importers/exporters) or up to $\$ 500$ per violation (for all violators, regardless of knowledge). The enforcing agency is required to give the offender notice and opportunity for a hearing before assessing the penalty. Criminal penalties for knowing violations may climb as high as $\$ 50,000$ per violation and/or one year's imprisonment. A self-defense argument against both civil and criminal penalties is available if the violator can prove that the offense was committed as a good faith reaction to the belief that an endangered or threatened species was going to cause bodily harm to the violator or another person.

Courts are authorized to issue warrants and injunctive relief, as well as to commit searches and seizures to enforce the ESA. In addition, private citizens may bring suit against violators, including the government, or against the agencies to compel enforcement of the ESA. Agencies may even go as far as to make arrests for violations of the ESA. Also, any equipment or property used in the violation of the ESA may be declared forfeited and seized by the agencies.

\section{What are the exceptions under ESA?}

The federal agencies administering the ESA are authorized to grant exceptions, usually by way of takings permits, to the prohibitions against takings. Permits may be granted for the following:

- Scientific purposes (conservation/propagation of an endangered species)

- The taking of an endangered species, if such a taking is incidental to, and not the purpose of, the performance of an otherwise lawful activity

- To apply for a takings permit under the second exception, the applicant must submit a Habitat Conservation Plan to either the Secretary of the Interior or the Secretary of Commerce, depending on whether the endangered species to be taken is a land or an aquatic animal, or to the Secretary of Agriculture if the endangered species to be taken is a plant.

In the Habitat Conservation Plan, the applicant must specify (1) the impact that will likely result from the taking; (2) what steps the applicant will take to minimize and mitigate the impact, and the funding that will be available to implement such steps; (3) what alternatives to the taking the applicant considered and the reasons why these alternatives are not being used; and (4) any other measures that the Secretary (of the Interior, Commerce, or Agriculture, depending on the type of endangered species which is taken) may require as being necessary or appropriate for purposes of the plan. The Secretary will issue the permit if the Secretary finds, after public notice and comment has been received, that the taking will be incidental; that the applicant will, to the maximum extent practicable, minimize and mitigate the impacts of the taking; that the applicant will ensure that adequate funding for the plan will be provided; that the taking will not appreciably reduce the probability of the survival and recovery of the species in the wild; and that all other additional measures required by the Secretary for the specific case, to be determined on a 
case-by-case basis, will be met. The permit can be revoked if it is found that the applicant is not complying with the terms and conditions of the permit.

\section{What are the exemptions under ESA?}

There are several exemptions from the ESA, including

1. The Hardship Exemption: This exemption is used in cases where the applicant has proven to the Secretary that the applicant had entered into a contract for the lawful taking of an animal or plant before it was placed on the endangered species list and that the listing will cause undue economic hardship to the applicant under the contract. Undue economic hardship includes substantial economic loss resulting from the inability to perform such contracts due to the listing of the species as endangered; substantial economic loss to people who for at least a year prior to the listing of the species derived a substantial portion of their income from the lawful taking of the now listed species; and the ending of the lawful taking of the species for food by people who are not reasonably able to secure other sources of food and who are substantially dependent on hunting and fishing for food. These permits are usually limited to allow takings only for one year following the designation of the species as endangered.

2. The Antique Articles Exemption: Basically, this exemption allows for the importation, exportation, transportation, possession, sale, and purchase in foreign and interstate commerce of antique articles made from threatened or endangered species (contact the EPA for a complete list of designated import ports and appropriate Customs import forms). This exemption covers only antique articles that

- Are at least 100 years of age

- Are composed in whole or in part of any listed threatened or endangered species

- Have not been repaired or modified with any part of any listed species on or after December 28, 1973

- Have entered at one of the designated ports within the Customs territory of the United States

For the complete list of exemptions from the ESA, contact the EPA.

For more information about the ESA, refer to the EPA website at https://www.epa.gov/laws-regulations/ summary-endangered-species-act.

\section{What is NEPA?}

In addition to the requirements of ESA, other laws should be consulted to address unintended consequences of proposed activities on protected species. The National Environmental Policy Act (NEPA), through the procedures it mandates, provides federal agencies the opportunity to consider environmental effects that will be caused by proposals for legislation and other major federal actions before they commence the project. NEPA requires that all federal agencies must include in every recommendation or report on proposals for legislation and other major federal actions significantly affecting the quality of the human environment a detailed written statement (Environmental Impact Statement [EIS]) on

- The environmental impact of the proposed action

- Any adverse environmental effects that cannot be avoided if the proposal is implemented

- Alternatives to the proposed action

- The relationship between local short-term uses of the environment and the maintenance and enhancement of long-term productivity

- Any irreversible and irretrievable commitments of resources that would be involved in the proposed action if it were implemented

If, after performing an EIS, the decision is to state a finding of no significant impact (FONSI), or if the agency does not perform an EIS due to a categorical exclusion, those findings may be challenged and overturned by judicial review (especially if the agency fails to follow the rules mandated under the Administrative Procedure Act [APA]).

In situations where an EIS is not required for a federal agency's action because the action is not a major federal action or when the action falls under a categorical exclusion, the federal agency can choose to perform an Environmental Assessment (EA) on the project/proposal to determine whether the federal agency should perform an EIS on the specific project (a step frequently taken by agencies) or to state a finding of no significant impact (FONSI). Just like an EIS, a federal agency through an EA can state a ruling of no significant impact (FONSI). For more information about NEPA, refer to the EPA website at http://www.epa.gov/ compliance/nepa/.

\section{What is APA?}

The Administrative Procedure Act (APA) mandates the requirements that the federal agencies must follow when they go through the process of making a rule. Basically, 
the rulemaking process requires that the federal agency determining whether or not to make a rule must first provide public notice, published in the Federal Register, of the proposed rulemaking which includes

- The time, place, and nature of the public rulemaking proceedings

- The legal authority under which the rule is being proposed

- Either the terms of the rule or a description of the subject and issues involved

The federal agency must provide the public with an opportunity to be heard through participation in the rulemaking process by submission of written data, views, or arguments, with or without the opportunity of oral presentation. After considering all of the relevant matter presented, the federal agency must incorporate into the rule(s) adopted a general statement of their basis and purpose.

The federal agency must publish the substantive rule in the Federal Register no less than 30 days before its effective date.

If the federal agency fails to follow these requirements, APA allows for judicial review of the agency's rule in some circumstances, but excludes judicial review if agency discretion is mandated by law. Only a person with standing may sue a federal agency for making a ruling. For more information about APA, refer to the EPA website at https://www.epa.gov/laws-regulations/ summary-administrative-procedure-act.

APA addressing the federal agency's violation of the requirements of prevents the federal agency from taking, or failing to take, an action that could negatively impact the environment or violate legislation such as ESA.

\section{Sources}

16 United States Code, Sections 1531 to 1544

\section{Acknowledgments}

The authors are indebted to the personnel of both state and federal agencies who provided their time and advice in the preparation of this handbook. We acknowledge Carol Fountain and Susan Gildersleeve at the University of Florida for their assistance in editing this handbook. We also acknowledge funding received for updating this publication from the James S. and Dorothy F. Wershow Agricultural Law Endowment. 